\title{
PERIFERINE் NEUROPATIJA IR ANGIOPATIJA SERGANT 2 TIPO CUKRINIU DIABETU
}

\author{
Liudmila Kimševaitè \\ Vilniaus miesto klinikiné ligoninè
}

Raktažodžiai: cukrinis diabetas, periferinè neuropatija, angiopatija, diabetinè pèda.

\begin{abstract}
Santrauka
Straipsnyje analizuojamos cukrinio diabeto komplikacijos - diabetinè periferinè neuropatija ir diabetinè angiopatija. Periferinè neuropatija ir angiopatija yra diabetinès pẻdos opų rizikos veiksniai. Kojų kraujotaka turi būti tikrinama visiems diabetu sergantiems ligoniams, svarbus kulkšnies-žasto indekso nustatymas. Opos pašalinimas, antibiotikų terapija ir revaskuliarizacija yra pagrindiniai diabetinès pédos opų valdymo metodai. Gliukozès ir hemoglobino HbA1C kontrolè, širdies ir kraujagyslių ligu rizikos veiksnių valdymas, rūkymo nutraukimas, infekcijos kontrolè yra diabetinès pèdos priežiūros principai. Didelès rizikos pacientai turi dalyvauti pẻdų priežiūros programoje. Anksti diagnozavus periferinę neuropatiją ir angiopatiją bei paskyrus gydymą, galima išvengti pẻdų opų ir amputacijos. Pateikti diabetinès periferinès neuropatijos ir angiopatijos klinikiniai atvejai. Apžvelgta naujausia mokslinè literatūra apie periferinę neuropatiją ir angiopatiją sergant 2 tipo cukriniu diabetu.
\end{abstract}

\section{Ivadas}

Cukrinio diabeto (CD) kraujagyslinės komplikacijos yra mikrovaskulinès (retinopatija, nefropatija, neuropatija) ir makrovaskulinès (koronarinè širdies liga, cerebrovaskulinè liga, periferinių kraujagyslių liga) [1]. Diabetinè periferinè neuropatija (DPN) sąlygoja dideli sergamumą, padidejusi mirtingumą ir pablogejusią gyvenimo kokybę [2]. DPN pasireiškia beveik 50\% sergančiųjų CD ir yra susijusi su skausmu, pėdų opomis ir apatinių galūnių amputacija [3]. DPN ir periferinių kraujagyslių liga (PKL) yra pagrindiniai diabetinių pèdų opų patogenezès veiksniai [4]. Diabetinès pedos opos yra rimta CD komplikacija visame pasaulyje ir dažniausia diabetu sergančių asmenų hospitalizavimo priežastis. Polineuropatija vaidina svarbų vaidmenį diabetinès pėdos opos patofiziologijoje [5]. Pèdų opų rizika yra $15 \%$ visiems diabetu sergantiems ligoniams, net $1 \%$ vyresnio amžiaus žmonių Vakarų pasaulyje yra rizika susirgti pėdos opa kaip CD komplikacija. Kai periferinių arterijų nepakankamumas komplikuoja neuropatiją, yra dešimt kartų didesnè opos perejjimo ị infekciją ir gangreną rizika. Diabetu sergančių ligonių kojų amputacijų dažnis yra 17-40 kartų didesnis, nei nesergančių diabetu $[6,7]$. Diabetinè pẻda skirstoma ị du pagrindinius tipus: neuropatines opas ir neuroišemines opas. Pastarujų atveju be neuropatijos yra ir PKL. PKL paplitimas ligoniams, sergantiems diabetinėmis pėdų opomis, yra 30 procentų. CD atveju 25\% ligonių pédos opos nulemia amputaciją [8]. Aktyvių pédų opų paplitimas svyruoja nuo maždaug 1\% Europos ir Šiaurès Amerikos studijose iki daugiau kaip 11\% kai kurių Afrikos šalių pranešimuose [9]. Diabetinè angiopatija išlieka pagrindine mirtingumo priežastimi [10]. Apie $25 \%$ iš 6 milijonų ligonių, sergančių CD Vokietijoje, kenčia nuo diabetinès pèdos sindromo. Šių ligonių mirtingumas yra daugiau kaip dvigubai didesnis, nei kitų gyventojų. $25 \%$ diabetu sergančių ligonių išlaidų tenka diabetinių pėdų opų gydymui, o $50 \%$ ligoninès dienų skiriama diabetinès pèdos sindromui gydyti [4]. Diabetinès pèdos opos gydymo kaina yra 5000 - 8000 JAV dolerių [6].

Darbo tikslas - pateikti ir išanalizuoti sergančiųų 2 tipo CD periferinès neuropatijos ir angiopatijos klinikinius atvejus, apžvelgti naujausią mokslinę literatūrą apie šias diabeto komplikacijas.

\section{Klinikiniai atvejai}

Ligonè S.T., 80 metų, skundèsi kojų skausmu, tirpimu. Serga hipertenzine širdies liga, CD. Objektyviai: AKS180/90 mmHg, P-68 k/min. Neurologinis tyrimas: „kojinių“ tipo jutimo sutrikimas kojose, susilpneję sausgysliniai refleksai kojose, pédos šaltos. Tyrimai: leuk.- $8,02 \cdot 10^{9} / 1$, eritr.$4,6 \cdot 10^{12} / 1, \mathrm{Hb}-145 \mathrm{~g} / 1$, tromb. $-219 \cdot 10^{9} / 1$, neutr.- $65,7 \%$, limf.$25,5 \%$, mon. $-6,6 \%$, eoz. $-2 \%$, baz.- $0,2 \%$, nesubr.gran. $-0,5 \%$, SPA-130\%, INR-0,91, D-dimerai - 1,06 $\mu \mathrm{g} / \mathrm{ml}$, FM-4,51 $\mathrm{mg} / \mathrm{l}$, šlapalas - 9,3 mmol/1, kreatinin. - $104 \mu \mathrm{mol} / \mathrm{l}$, GFG - $60 \mathrm{~mL} / \mathrm{min} / 1,73 \mathrm{~m}^{2}$, gliuk.-8,68 mmol/1, HbA1C-6,3\%, 
bendr.cholest.-6,65 mmol/1, bendr. balt.-71,5 g/1, CRB-3,78 $\mathrm{mgl} / 1, \mathrm{~K}-5,92 \mathrm{mmol} / 1$, Na-140 mmol/1, bendr. šlapimo tyrimas - norma. EKG: ritmas sinusinis, ŠSD - 69/min. Krūtinès ląstos rentgenografija: plaučiuose židininių, infiltracinių pakitimų nematyti, aortos lankas sklerozuotas. Vidaus organų echoskopija: praplèstos hepatinès venos, inkstų cistos. Kraujagyslių chirurgas: paryškẻjęs kapiliarų tinklas pėdose ir blauzdų distalinėse dalyse, silpni pulsai pėdose, pėdų kapiliarinè kraujotaka vangesnè, pėdos vėsios. Doplerometrija: pèdų kraujotaka normali. Diagnozè: $C D, 2$ tipas, vidutinio sunkumo forma, subkompensacija. Diabetinè angiopatija. Diabetinè distalinè simetrinė sensomotorinė kojų polineuropatija. Hipertenzinè širdies liga, II $^{0} \mathrm{AKS}$ padidejjimas, didelès rizikos grupè. Inkstų cistos. Gydymas: insulinu detemiru, metforminu, olmesartanu ir amlodipinu, betaksololiu, moksonidinu, duloksetinu, B grupès vitaminais, fizioterapija.

Ligonis N.P., 72 metų, skundèsi dešinès kojos skausmu einant, abiejų pẻdų tirpimu ir šalimu. Serga CD. Objektyviai: AKS-140/85 mmHg, P-78 k/min. Pulsai čiuopiasi tik kirkšnyse, distaliau nečiuopiami. Dešinès pėdos kapiliarinė kraujotaka vangesnè, pèda blyškesnè, vėsesnè. Dešinès pèdos II piršto paviršine opelè. Neurologinis tyrimas: „kojinių“ tipo ir giliojo jutimo sutrikimas kojose, sumažèjęs kojų raumenų tonusas, susilpnèję sausgysliniai refleksai kojose, pèdos šaltos, pabrinkusios, dešinè pèda cianoziška. Tyrimai: leuk.$10,22 \cdot 10^{9} / 1$, eritr.-4,64 $\cdot 10^{12} / 1, \mathrm{Hb}-151 \mathrm{~g} / \mathrm{l}$, tromb.- $182 \cdot 10^{9} / 1$, neutr.-60,6\%, limf.-29,9\%, mon.-8,4\%, eoz.-0,8\%, baz.0,3\%, nesubr.gran.-0,8\%, DATL-32,5 s, SPA-99\%, INR-1, fibrinog. - 4,67 g/l, šlapalas - 5,7 mmol/1, kreatinin.-105 $\mu \mathrm{mol} / \mathrm{l}$, GFG- $61 \mathrm{~mL} / \mathrm{min} / 1,73 \mathrm{~m}^{2}$, bendr. bilirubin.-17,6 $\mu \mathrm{mol} / \mathrm{l}$, bendr.cholest. - $6,61 \mathrm{mmol} / \mathrm{l}$, DTL cholest. - 1,93 $\mathrm{mmol} / \mathrm{l}$, MTL cholest. - 4,35 mmol/1, gliuk.-6,14 mmol/1, bendr.balt.-76,9 g/l, CRB-30,54 mg/1, K-4,69 mmol/1, Na$136 \mathrm{mmol} / \mathrm{l}$. EKG: ritmas sinusinis, ŠSD - $69 \mathrm{k} / \mathrm{min}$. Vidaus organų echoskopija: inkstų parenchimos amžiniai pakitimai. Doplerometrija: postokliuzinis signalas dešinèje pėdoje. KŽI dex. - 0,37, KŽI sin. - 0,5. Dešinès kojos angiografija: dešinès AIC, AIE stenozès, AFS, AP, aa. cruris okliuzijos. Diagnozè: CD, 2 tipas, vidutinio sunkumo forma, subkompensacija. PAL. Diabetinè angiopatija. Abiejų kojų lètinè išemija, stadija IIB-III. Dešinès pedos II piršto paviršinė opa. Diabetinè distalinè simetrinè sensomotorinè kojų polineuropatija. Gydymas: metforminu, cilostazoliu, klopidogreliu, acetilsalicilo rūgštimi, atorvastatinu, pregabalinu, B grupès vitaminais. Atlikta AIC dex. $>50 \%$ stenozès PTA.

Ligonė G.V., 87 metų, skundèsi kojų pirštų skausmu, kojų tirpimu. Serga CD, KŠL, PV, implantuotas EKS. Objektyviai: AKS-120/70 mmHg, P-80 k/min. Neurologinis tyrimas: „kojinių“ tipo jutimo sutrikimas ir parestezijos kojose, sausgysliniai refleksai kojose susilpnèję $\mathrm{s}=\mathrm{d}$, šaltos peddos. Tyrimai: leuk.-6,39 $10^{9} / 1$, eritr.-4,07 $10^{12} / 1$, Hb-117 g/l, tromb.- $171 \cdot 10^{9} / 1$, neutr.-60,2\%, limf.-28,8\%, mon.- $10,2 \%$, eoz.- $0,5 \%$, baz.- $0,3 \%$, nesubr.gran.-0,3\%, SPA$112 \%$, INR-0,96, fibrinog. - 4,67 g/l, šlapalas - 9,2 mmol/1, kreatinin.-85 $\mu \mathrm{mol} / 1$, gliuk.-5,9 mmol/1, HbA1C - 6,3\%, bendr. cholest.-7,82 mmol/1, DTL- cholest.-1,79 mmol/1, MTL - cholest.-5,67 mmol/1, bendr.balt.-70,5 g/1, CRB-0,42 $\mathrm{mg} / \mathrm{l}, \mathrm{K}-4,46 \mathrm{mmol} / \mathrm{l}, \mathrm{Na}-138 \mathrm{mmol} / \mathrm{l}$. EKG: EKS veikla, ŠSD-70 k/min. Krūtinès ląstos rentgenografija: plaučiuose židininių, infiltracinių pakitimų nematyti. Vidaus organų echoskopija: periportinès fibrozès požymiai. Kraujagyslių chirurgas: blauzdose ryškus kapiliarų ir venų tinklas, silpni pulsai pèdose, kapiliarinè kraujotaka pėdose vangesnè, kairès blauzdos viršutiniame paviršiuje šašu dengta opelè, dešinès pedos III piršto nuospauda. Doplerometrija: pèdų kraujotaka normali. Diagnozė: CD, 2 tipas, vidutinio sunkumo forma, subkompensacija. Diabetinè angiopatija. Diabetinè distalinè simetrinè sensomotorinė kojų polineuropatija. KŠL. Lètinis PV. EKS implantavimas $2018 \mathrm{~m}$. ŠN C stadija, NYHA III. Dislipidemija. Gydymas: metforminas, gliklazidas, pentoksifilinas, deksketoprofenas, pregabalinas, B grupès vitaminai, metoprololis, perindoprilis, rivaroksabanas, torazemidas, atorvastatinas.

Ligonis K. M., 71 metų, hospitalizuotas dèl pūliuojančios žaizdos kaireje pedoje. Serga CD. Objektyviai: AKS-130/80 $\mathrm{mmHg}, \mathrm{P}-76$ k/min. Kojų kraujotaka kompensuota, pulsai pakinkliuose, pėdose pulsų nèra, paryškẻjęs kapiliarų tinklas pedose. Kairès pèdos pirštai amputuoti, pirštų pagrindų srityje matoma fistulè, iš kurios išsispaudžia pūliai. Dešinès pedos II-IV pirštai amputuoti, operacinès žaizdos sugijusios. Neurologinis tyrimas: „,kojinių“ tipo jutimo sutrikimas kojose, sausgysliniai refleksai kojose žemi $s=d$, pedos šaltos, kairè pėda cianoziška, patinusi. Tyrimai: leuk.-8,62 $10^{9} / 1$, eritr.-3,39 $10^{12} / 1, \mathrm{Hb}-106 \mathrm{~g} / 1$, tromb.-231 $10^{9} / 1$, neutr. $-82,8 \%$, limf.- $-6,2 \%$, mon. $-10,1 \%$, eoz. $-0,6 \%$, baz. $-0,3 \%$, nesubr. gran.-1,4\%, K-4,89 mmol/1, Na-139 mmol/1, DATL-35,5s, SPA-115\%, INR-0,95, fibrinog.-7,07 g/l, gliuk.-9,01 mmol/1, CRB-272,6 mg/l. Žaizdos pasèlis: labai gausiai išaugo Staphylococcus aureus, gausiai - Finegoldia magna. Krūtinès ląstos rentgenografija: plaučiuose židininių, infiltracinių pakitimų nematyti. Kairès pedos rentgenografija: kairès pedos pirštakauliai amputuoti, II padikaulio galvutėje destrukcinis židinys, ties II padikauliu - minkštujjų audinių defektas. Angiografija: ATA sin. > 50\% stenozè. Diagnozè: CD, 2 tipas, vidutinio sunkumo forma, subkompensacija. Diabetinè angiopatija. Diabetinè distalinè simetrinè sensomotoriné kojų polineuropatija. Diabetinè pẻda. Kairès pèdos pūlinys. Būklè po kairès pèdos pirštų amputacijos. Obliteruojanti aterosklerozé, IV B stadija. Kairès priekinès blauzdos arterijos stenozė. Gydymas: insulinu detemiru, amoksicilinu 
ir klavulano rūgštimi, klopidogreliu, acetilsalicilo rūgštimi, gabapentinu, deksketoprofenu, B grupès vitaminais. Atlikta kairès pèdos II-IV padikaulių rezekcija ir ATA sin. $>50 \%$ stenozès PTA.

\section{Literatūros apžvalga ir diskusija}

Siekta nustatyti diabetinès neuropatijos ir periferinių arterijų ligos (PAL) klinikinius ir metabolinius rizikos veiksnius ligoniams, gydomiems diabetinès pėdos skyriuje. Tirti 304 CD sergantys ligoniai. Jie suskirstyti ị keturias grupes: be patologijos (normali grupè), su neuropatija (neuropatinè grupé), su PAL (kraujagyslių grupè) ir su abiem patologijomis (mišri grupè). Išanalizuotos šios charakteristikos: amžius, lytis, diabeto tipas, trukmè, mikrovaskulinès ir makrovaskulinès komplikacijos, hipertenzija, rūkymo ịpročiai, antiagregacija ir vidutinis $\mathrm{HbA1C}$ praejusiais metais. Amžiaus, hipertenzijos ir KŠL dažnio rodmenys kraujagyslių ir mišrioje grupèse buvo žymiai didesni $(\mathrm{p}<0,005)$, nei normalioje grupejje (63 \pm 13 ir $65 \pm 10$ palyginus su $55 \pm 14 ; 69,2 \%$ ir $70,3 \%$ palyginus su $45,5 \% ; 46,2 \%$ ir $39,2 \%$ palyginus su $23,8 \%$ atitinkamai). Retinopatijos, nefropatijos ir HbA1C dažnis buvo žymiai didesnis $(\mathrm{p}<0,05)$ neuropatinejje ir mišrioje grupèse, nei normalioje grupeje $(62,5 \%$ ir $66,2 \%$ palyginus su $32,7 \% ; 45,3 \%$ ir $47,3 \%$ palyginus su $24,8 \% ; 8,1 \pm 1,6 \%$ ir $8,0 \pm 1,3 \%$ palyginus su $7,4 \pm 1,2 \%$ atitinkamai). Tyrimas parodè, kad diabetinès neuropatijos vystymasis susijęs su blogesne medžiagų apykaitos kontrole ir kitų mikrovaskulinių komplikacijų buvimu. Amžius, hipertenzija ir KŠL yra PAL rizikos veiksniai [11]. Periferinès neuropatijos paplitimas priklauso nuo amžiaus, diabeto trukmès, gliukozès kontrolès [3]. Tirtas neuropatijos paplitimas 2 tipo CD sergantiems ligoniams ir jos ryšys su kitomis diabeto komplikacijomis. Mičigano neuropatijos klausimyno duomenimis, somatinès neuropatijos paplitimas vyrams buvo $2,2 \%$, moterims $-5,5 \%(\mathrm{p}<0,001)$, tuo tarpu klinikinio tyrimo metu somatinè neuropatija nustatyta $30,5 \%$ vyrų ir $30,8 \%$ moterų. Ligoniams, sergantiems somatine neuropatija, makro - ir mikrovaskulinès diabeto komplikacijos buvo žymiai dažnesnès. Logistinès regresijos analizė KMI, HbA1C ir KŽI numatė neuropatijos buvimą. Klinikiniu tyrimu nustatyta, kad somatinės neuropatijos paplitimas sergant 2 tipo $\mathrm{CD}$ yra apie $30 \%$. Bloga medžiagų apykaitos kontrolè, per didelis kūno svoris ir periferinè arteriopatija yra nepriklausomi somatinès neuropatijos žymenys [12]. Šiaurès Anglijoje atlikta studija parodè, kad 42\% 2 tipo CD sergančių ligonių stebèti klinikiniai neuropatijos požymiai. Intensyviai gydant ir optimaliai kontroliuojant glikemiją, neuropatijos dažnị galima sumažinti 50 procentų. Manoma, kad hiperglikemija yra pagrindinis etiologinis veiksnys vystantis diabetinei neuropatijai. Neuropatijos negalima diagnozuoti vien anamneze, reikalingas kruopštus pėdų tyrimas dẻl jutimo praradimo ir kraujotakos ivvertinimas kiekvienam ligoniui kasmet. Periferinè neuropatija ir PKL yra pagrindiniai veiksniai, lemiantys pédos opų atsiradimą. Be to, pedos formos anomalijos ir plantar callus yra pedos opos rizikos veiksniai [13]. Siekta įvertinti PKL paplitimą sergant 2 tipo CD. Neuroišeminès opos buvo $30 \%$ ligonių, neuropatinès opos $-70 \%$ ligonių. Neuroišeminès opos buvo paplitusios tarp vyru (21/64 vyrai, palyginus su 9/36 moterimis). Nustatytas tvirtas rūkymo (20/30 ligoniu), hipertenzijos (24/30 ligonių) ir ilgesnès CD trukmès (14 ir 8 metų) ryšys su neuroišeminemis opomis. Net ir kitos CD komplikacijos, tokios kaip vainikinių arterijų liga (8/30 ligonių), insultas (4/30 ligonių), retinopatija (24/30 ligonių) ir nefropatija (15/30 ligonių) buvo labiau paplitusios ligoniams, sergantiems neuroišeminėmis opomis. PKL paplitimas yra 30 procentų. Neuropatinès opos yra du kartus dažnesnès už neuroišemines opas. Sergantiems hipertenzija vyrams, rūkantiems ir ilgiau sergantiems CD neuroišeminès opos atsiranda dažniausiai [8]. Siekta nustatyti mikro- ir makrovaskulinių komplikacijų paplitimą sergant 2 tipo CD Šiaurès Vakarų Indijoje ir jo sąsają su įvairiais rizikos veiksniais. Tirti 11157 asmenys, lankantys diabeto kliniką. Retinopatija diagnozuota $32,5 \%$, nefropatija - 30,2\%, DPN $-26,8 \%$, PKL $-28 \%$ asmenų. Daugkartinè logistinè regresinè analizė parodè, kad amžius turèjo reikšmingą ryši su retinopatija, DPN, KŠL ir PKL. Aukštesnis HbA1C padidino retinopatijos, neuropatijos ir nefropatijos riziką. Hipertenzija buvo susijusi su nefropatija ir KŠL. Nustatytas didelis kraujagyslinių komplikacijų paplitimas sergant 2 tipo CD Šiaurès Vakaru Indijoje [14].

Diabetinès neuropatijos patogenezè yra sudètinga. Lètinè hiperglikemija yra pagrindinis veiksnys, sukeliantis nervinių skaidulų pažeidimą. Didelis gliukozès kiekis stimuliuoja poliolio kelią, sukeliantị osmozinį stresą, ir padidina reaktyviujų deguonies rūšių susidarymą. Jis vaidina svarbų vaidmeni, vystantis diabetinei angiopatijai [2]. Hiperglikemijos sukelto poliolio kelio hiperaktyvumas, susijęs su nervų sorbitolio kaupimu ir mioinozitolio išsekimu, gali turetti įtakos diabetinès neuropatijos genezei. Mikroangiopatija yra pagrindinė DPN priežastis. Yra daugybe įrodymų, siejančių endoneuriumo mikrovaskulinius pokyčius su periferinių nervų disfunkcija sergant $C D$. Šie struktūriniai pokyčiai lemia nenormalų difuzijos barjerą, sukeliantị endoneurinę hipoksiją. Endoneuriumo mikrovezikulių funkciniai pokyčiai, pasižymintys sumažejusiu kraujagyslių išsiplètimu ir sustiprejjusia vazokonstrikcija, taip pat sustiprina endoneurinę hipoksiją. Nors DPN atveju sumažèja endoneurinio kraujo tékmè, yra tam tikru įrodymų, kad ankstyvoje ligos stadijoje kraujotaka gali pagreitèti. Esant DPN, pasireiškia kapiliarinè disfunkcija, dèl to sumažèja deguonies ir gliukozès 


\section{8}

kiekis, kurị audinys gali ịsisavinti esant tam tikrai kraujo tèkmei, t.y. audinys gali būti hipoksinis net esant normaliai ar pagreitejusiai nervų kraujotakai. Atlikti tyrimai išryškino glaudų endoneuriumo mikroangiopatijos ir DPN ryšį [1518]. Manoma, kad CD atveju metaboliniai ir hemodinaminiai veiksniai sąveikauja ir sukelia diabetinių kraujagyslinių komplikacijų išsivystymą. Pažengusi glikacija yra svarbus diabetinių komplikacijų patogenezès kelias. Yra įrodymų, kad šio proceso inhibitorius aminoguanidinas silpnina įvairių diabetinių kraujagyslinių komplikacijų vystymąsi. Eksperimentinių tyrimų rezultatai leido atlikti plataus masto klinikinius įvairių terapinių medžiagų tyrimus, kurios trukdo metaboliniams ir hemodinaminiams keliams, susijusiems su diabetinių komplikacijų progresavimu [1]. Patologiniai ir elektrofiziologiniai tyrimai rodo, kad simetrinei polineuropatijai būdingas mielininių ir nemielininių aksonų pažeidimas. Daugiažidininis aksoninès degeneracijos pobūdis ir jo ryšys su kraujagyslių liga rodo išeminę priežastị, susijusią su endoneurine mikrovaskuline cirkuliacija. Panašu, kad pagrindiniai biocheminiai pokyčiai yra glikozilintų galutinių produktų (GGP) gamyba esant lètinei hiperglikemijai, kurie kaupiasi ant endotelio baltymų, sukeldami bazinès membranos sustorejjimą ir endotelio ląstelių pakitimus. Tai sukelia daugiažidinines kraujagyslių ligas, kurios savo ruožtu sumažina nervų kraujotaką, sukelia endoneurinę hipoksiją ir generuoja laisvuosius deguonies radikalus. Dèl to atsiranda daugiažidininių išeminių neuronų pažeidimų [19]. Analizuoti diabetinès angiopatijos patofiziologiniai mechanizmai. Ryšs tarp lètinès hiperglikemijos ir kraujagyslių pažeidimo nustate keturi nepriklausomi patogenezès keliai: padidejjęs poliolio kelio srautas, padidèjęs GGP susidarymas, baltymų kinazès C aktyvacija, padidejęs heksozamino takų srautas. Šie, atrodo, nesusiję keliai turi pagrindinį bendrą poveikį: superoksido perprodukcija mitochondrijų elektronų transportavimo grandinejje. Mitochondrijų reaktyviosios deguonies rūšys iš dalies slopina glikolizinị fermentą gliceraldehidro-3-fosfato dehidrogenazę, kuri nukreipia padidejusị substrato srautą nuo glikolizès iki gliukozès perteklinio naudojimo. Tai suteikia naują pagrindą tyrimams ir vaistų kūrimui. Akivaizdu, kad keli patofiziologiniai veiksniai veikia vienu metu. Smulkiuju kraujagyslių liga vaidina svarbų vaidmenị diabetinės neuropatijos vystymesi. Mikroangiopatija ir ịvairių medžiagų apykaitos pokyčiai dèl hiperglikemijos yra glaudžiai tarpusavyje susiję [20, 21]. Studijuotas angiopatijos ir neuropatijos vystymosi mechanizmo tarpusavio ryšys ligoniams, sergantiems 2 tipo CD. Ligos genezejje svarbų vaidmenį atlieka skirtingi medžiagų apykaitos, imuniniai, hipoksiniai, genetiniai veiksniai, sukeliantys arterijų mikrocirkuliacijos ir periferinès nervų sistemos pažeidimą. Stambiujų ir smulkiųų kraujagyslių pokyčiai susiję su diabetine neuropatija [22].
Naujausi duomenys patvirtina hipotezę, kad komplemento sistemos ir tumoro nekrozès faktoriaus (TNF) superšeimos disreguliacija gali būti susijusi su diabetinių kraujagyslinių komplikacijų atsiradimu. TRAIL perspektyvus žymuo tiesiogiai susijęs su diabetinès angiopatijos vystymusi. Diabetinès angiopatijos patogenezèje gali dalyvauti su TNF susijęs apoptozę sukeliantis tigandas ir osteoprotegerinas. Jau egzistuoja keli būdai, kaip specialiai manipuliuoti komplemento ir TNF superšeimos sistemomis, tačiau vis dar neatskleidžiama, ar šie vaistai efektyvūs vèlyvujų diabetinių komplikacijų gydymui [10].

Atliktas diabetinès pèdos kraujagyslių ir nervų pažeidimų morfologinis tyrimas. Sergant diabetine neuropatija, sutrikęs neurogeninis hemodinamikos reguliavimas gali prisidèti prie mikroangiopatijos vystymosi. Tyrimas atliktas su 25 ligoniu grupe: 91 tipo CD ir 162 tipo CD sergančių ligonių. Visi ligoniai sirgo DPN, jiems buvo ịvairaus laipsnio pėdų pažeidimas. Visais atvejais buvo reikalinga pėdu amputacija. Audinių fragmentai buvo panaudoti standartiniam histopatologiniam tyrimui. Histopatologinis tyrimas atskleide odos pažeidimo lygi - opos, apimančios didelius plotus, hiperakantozè. Mikroskopiškai odoje nustatytas uždegiminis infiltratas. Stebima prakaito liaukų degeneracija, veninè stazè ir perivaskulnès kraujosruvos. Stambiose arteriolèse ir arterijose stebimas pluoštinis audinys, kalcio nuosedos ant intimos, mediokalcinozè. Diabetinès pédos morfologiniai pokyčiai apima epidermi, dermą ir raumenis [23].

Atnaujinti diabetinès angiopatijos diagnostikos metodai [24]. Raumenų kapiliarų bazinės membranos sustorèjimas (BMS) ir padidejęs albumino ekskrecijos greitis (AEG) yra generalizuotos diabetinès mikroangiopatijos požymiai ir gali būti susiję su neuropatijos sunkumu. Tirta 19 ligonių, sergančių ilgesne nei dvylikos mėnesių neuropatija. Ivvertinti neuropatijos sunkumo ir raumenų kapiliarų BMS, AEG, retinopatijos buvimo, amžiaus ir diabeto trukmès ryšiai. Devyni ligoniai sirgo retinopatija. Diabetu sergančių ligonių su retinopatija diabeto trukmẻ buvo žymiai ilgesnè (vidutinè trukmè - 22 metai; 3-42 metai) palyginus su ligoniais, kuriems nebuvo retinopatijos (6 metai, 1-20 metų; $p<0,05$ ). Sergančiųų retinopatija raumenų kapiliarų BMS buvo reikšmingai didesnis (3,077A), ligonių be retinopatijos - 1,599A. Retinopatija sergančių ligonių AEG buvo didesnis - vidutiniškai $88 \mu \mathrm{g} / \mathrm{min}$. $(8-200 \mu \mathrm{g} / \mathrm{min}$.), palyginus su ligoniais be retinopatijos - $8 \mu \mathrm{g} / \mathrm{min}$. $(2-63 \mu \mathrm{g} / \mathrm{min} ., \mathrm{p}<0,05)$. Esant retinopatijai, žymiai sunkesni neuropatijos požymiai 12 balų neurofiziologinejje skaleje $(p<0,05)$. Studija parodè ryši tarp retinopatijos ir neuropatijos sunkumo, tačiau tarp neuropatijos sunkumo ir AEG bei raumenų kapiliarų BMS ryšio nenustatyta. Sunki lètinè periferinè neuropatija yra susijusi su mikroangiopatinèmis komplikacijomis [25]. Nustatytas 
kraujotakos makrovaskulinès hiperemijos atsako (MHA) sumažejjimas diabetikams, sergantiems DPN. Ultragarsiniu dopleriu tirtas $51 \mathrm{CD}$ sergantis ligonis. Sumažèjusio MHA dažnis esant somatinei neuropatijai buvo $69,7 \%$, autonominei neuropatijai - 75,7\% visų ligonių. Rezultatai rodo, kad diabetinių pėdų kraujotakos MHA yra sumažėjęs jau ankstyvoje DPN stadijoje, kai dar nèra periferinių kraujagyslių okliuzinès ligos [26]. CD yra susijęs su padidejjusiu PAL paplitimu ir medialine arterine kalcifikacija (MAK), galimai susijusia su diabetinès polineuropatijos paplitimu ir sunkumu. Tirta 260 diabetine polineuropatija sergančių ligonių ir 221 sveikų asmenų. Atliktos standartinès pèdų rentgenogramos. Tirtas MAK paplitimas, rizikos variantai, koreliacija su PAL ir itaka distalinei sensomotorinei polineuropatijai. Iš 481 tiriamojo MAK nustatyta 66(13,7\%): 55 iš 260(21,2\%) ligonių, sergančių CD ir 11 iš 221(5,0\%) sveikų asmenų $(\mathrm{p}<0,001)$. MAK buvo reikšmingai susijusi su distaline sensomotorine polineuropatija $(\mathrm{p}<0,001)$. Atliekant laipsnišką logistinès regresijos analizę, reikšmingi rizikos veiksniai, susiję su MAK, buvo amžius, vyriška lytis, $\mathrm{CD}$ ir retinopatija. Kojų MAK buvo beveik keturis kartus dažnesnè CD sergantiems ligoniams nei sveikiems asmenims. Kojų MAK, nors ir reikšmingai susijusi su distaline sensomotorine polineuropatija, nebuvo jos žymuo. Nebuvo įrodyta, kad MAK gali nulemti distalinès sensomotorinès polineuropatijos pablogéjimą, tačiau PAL gali pabloginti distalinę sensomotorinę polineuropatiją [27]. Arterinio nepakankamumo klinikinès manifestacijos ir kraujagyslių pažeidimo charakteristikos palygintos 68 ligoniams (54 vyrai, 14 moterų, amžiaus vidurkis $64,5 \pm 1,1$ metų), sergantiems kojų arterijų ateroskleroze, įskaitant 40 ligonių, sergančių 2 tipo CD. Spalvinis dvigubas skenavimas atliktas kraujagyslių sienelių pažeidimui ịvertinti. Kulkšnies kraujospūdis matuotas doplerio metodika, apskaičiuojant KŽI. Kojų arterijų aterosklerozè ligoniams, sergantiems $\mathrm{CD}$, kliniškai pasireiškẻ kaip neuropatija. Protarpinis šlubumas labiau būdingas nesergantiems CD. Medialinès arterinès kalcinozès sunkumas ir kraujagyslių sienelių standumas buvo susijęs su CD trukme. CD sergančių ligonių KŽI buvo 1,5 - 2 kartus didesnis, palyginus su nesergančiujų $\mathrm{CD}$, kuriems yra kojų kraujagyslių okliuziniai ir neokliuziniai pokyčiai. Daugybinių aterosklerotinių plokštelių dažnis pilvo aortos, klubinèse ir pakinklio arterijose atliekant spalvinị dvigubą skenavimą sergančiųjų CD ir nesergančiųjų CD grupèse nesiskyrè [28]. Atliktas pèdų temperatūros palyginimas tarp diabetikų su neuropatinėmis, kraujagyslinėmis, neurovaskulinėmis komplikacijomis ir be jų. Tyrimui naudota infraraudonujų spindulių termografija (IST), siekiant išanalizuoti CD sergančių ligonių su neuropatija, vaskulopatija, neurovaskulinėmis komplikacijomis ar be jų pėdų temperatūros skirtumą, segmentuojant pedos padą keturiose tyrimo srityse. 277 ligoniai, sergantys CD (138 vyrai ir 139 moterys), kurių vidutinis amžius $63,41 \pm 17,69$ metų, KMI 29,08 $\pm 5,86$, buvo suskirstyti ị keturias grupes: 22(7,94\%) su neuropatija, $32(11,55 \%)$ su vaskulopatija, $83(29,96 \%)$ su neurovaskulopatija ir $140(50,54 \%)$ - be komplikacijų. Taigi, beveik pusei ligonių $(49,46 \%)$ buvo tam tikros rūšies komplikacijų. Fotografiniai vaizdai atlikti naudojant infraraudonujų spindulių kameros modeli FLIR E60bx ${ }^{\circledR}$. Gauti duomenys analizuoti naudojant „IBM SPSS Statistics 22“ statistikos programą. Ligoniams su neuropatija, vaskulopatija ir neurovaskulopatija po pirmo padikaulio galvute, penktaja padikaulio galvute, abiejų kairiujų ir dešiniujų kojų didžiojo piršto padu buvo nustatyta žemesnè temperatūra. Nustatyta, kad IST naudinga, nustatant polinkị pažeidimams tam tikruose pèdos regionuose, o tai svarbu ankstyvam gydymui [29]. Lètinès diabeto komplikacijos gali būti tiriamos nuotoliniu būdu, naudojant palydovą (DIABSAT telemedicina). Transporto priemonèje yra palydovinè antena ir medicininè ịranga, skirta patikrinti akių, inkstų, kraujagyslių ir neuropatinius pažeidimus bei ịvertinti diabetinès pėdos opos rizikos laipsnị. Duomenys ịvedami ị kompiuterị ir perduodami palydovu specialistų vertinimui. Tirti 1545 ligoniai. Vidutinis amžius - 70,7 metai, $55,8 \%$ vyrų. 93,4\% ligonių diagnozuotas 2 tipo $\mathrm{CD}$, vidutinè trukmè - 11,7 metų. 18,7\% ligonių nustatyta diabetinè retinopatija, 31,9\% - mikroalbuminurija, 17,2\% - kojų arteriopatija, $28,3 \%$ - periferinè neuropatija, $28,2 \%$ - didelè pédų opų rizika ( $\left.\mathrm{II}^{\circ}-20,6 \%, \mathrm{III}^{\circ}-7,6 \%\right)$. Didelis patikrintų ligonių ir nustatytų komplikacijų skaičius patvirtina nuotolinio stebejjimo gyvybingumą ir tinkamumą [30].

Siekta nustatyti ryši tarp PAL ir neuropatijos sergant 2 tipo CD. Tirta 80 CD sergančių ligonių (51 moteris ir 29 vyrai). Vidutinis amžius - 53,9 $\pm 9,6$ metai, vidutinis $C D$ progresavimas - $8 \pm 6,6$ metų, vidutinis gliukozès kiekis buvo $283 \pm 110 \mathrm{mg} / \mathrm{ml}$. Neuropatija pasireiškè $65(81,2 \%)$ ligoniams. KŽI tirtas 19\% ligonių, jiems nustatytas vidutinio sunkumo periferinių kraujagyslių nepakankamumas. Motorinių nervų laidumo greitis buvo sutrikęs $40 \%$ ligonių, H-reflekso nebuvo $70 \%$ ligonių. II $^{0}$ sensomotorinè neuropatija diagnozuota 70-80\% ligonių, periferinių kraujagyslių nepakankamumas - 19\% CD ligonių. Studijos duomenimis, diabetinè neuropatija pasireiškè prieš periferinių kraujagyslių pažeidimus [31]. Siekiant ištirti diabetinès pèdos su neuropatija charakteristikas ir su ja susijusius veiksnius, apklausta 530 ambulatorinių ir stacionarinių ligonių, turinčių pėdos problemų. 337 iš 500 ligoniu $(63,58 \%)$ sirgo neuropatija, 172(32,45\%) - neuropatija, kombinuota su PAL. 193 iš 500 ligoniu (36,42\%) sirgo PAL. 77,7\% ligonių opos atsirado dèl fizinių veiksnių. Ligonių, sergančių neuropatija, diabetinès pėdos trukmė buvo 3(1,60) mènesiai, žymiai trumpesnè nei 
diabetine pėda sergančių ligonių su PAL - 5(1,96) mėnesiai, $\mathrm{p}<0,001$. Diabetinès pédos su neuropatija gijimas yra ankstesnis už diabetinès pèdos su PAL gijimą. Neuropatija ir PAL turi įtakos viena kitai ir pablogina diabetinès pèdos būklę [32]. Tirtas hipertenzijos, dislipidemijos, nutukimo, makro- ir mikroangiopatijos dažnis 2 tipo CD sergantiems ligoniams, turintiems ir neturintiems odos žymos. Tirti 99(40 moteru ir 59 vyrai) ligoniai, sergantys 2 tipo CD. Visiems matuotas AKS, nustatytas KMI, HbA1C, atlikta lipidograma, nustatyta makroangiopatija (PAL, cerebrovaskulinè liga, KŠL), mikroangiopatija (neuropatija, nefropatija, retinopatija) ir odos žymos. Amžius, $\mathrm{HbA1C}$ ir KMI buvo atitinkamai 65,0 $\pm 14,2$ metai, $8,1 \pm 2,0 \%$ ir $30,5 \pm 6,4 \mathrm{~kg} / \mathrm{m}^{2}$. Odos žymu dažnis - 53,5\%, dislipidemija - 68,7\%, hipertenzija - 69,7\%, nutukimas - 39,4\%, makroangiopatija - 61,6\% (PAL - 12,1\%, cerebrovaskulinè liga - 16,2\%, KŠL - 49,5\%), mikroangiopatija - $63,6 \%$ (neuropatija - 21,2\%, nefropatija - 38,4\%, retinopatija - 38,4\%). Didesnis KMI ir nutukimo dažnis nustatytas ligoniams, turintiems odos žymą. Amžius, lytis, HbA1C, dislipidemija, hipertenzija, makroangiopatija ir mikroangiopatija nesiskyre ligoniams, turintiems ir neturintiems odos žymos. Sergant CD, odos žymos buvimas yra susijęs tik su nutukimu [33]. Tirti 225 ligoniai. Siekta ịvertinti diabetikų neuropatinị skausmą ir PAL, palyginti šias ligas su laiko tarpu nuo diagnozès pradžios, nustatant 1 ir 2 tipo diabetą. Buvo nustatomas KŽI ir naudotas DN4 klausimynas. Didesnis neuropatinio skausmo dažnis vyresniems nei 60 metų asmenims parode KŽI $>1,3$. Neuropatinis skausmas buvo susijęs su pakitusiu KŽI 144(64,2\%) ligoniams. Statistiškai reikšmingas skirtumas gautas ligoniams, sergantiems 2 tipo $\mathrm{CD}$, kuriems nuo ligos pradžios praejjo daugiau nei 10 metų (69 ligoniams - su pakitusiu KŽI ir 25 - su normaliu KŽI). KŽI buvo pakitęs $(<0,9) 33 \% 1$ tipo CD sergančiujų ir $67 \% 2$ tipo CD sergančiujų. KŽI nustatymas 1 ir 2 tipo CD sergantiems ligoniams yra svarbus net tuo atveju, kai nèra simptomų. Ilgesnè nei 10 metų CD trukmè, neatsižvelgiant ị neuropatinio skausmo ar išemijos požymių buvimą, pakeite KŽI [34].

DPN skirstoma ị simetrinę ir asimetrinę formas. Simetrinè forma dažniausiai yra jutiminè ar autonominè, o asimetrinè forma gali būti jutiminè, motorinè ir mišri. Distalinė simetrine polineuropatija yra dažniausiai pasitaikantis DPN tipas [2,19]. Visiems mūsų tirtiems ligoniams buvo diabetinè distalinè simetrinè sensomotorinè polineuropatija. Apie 70\% ligonių, sergančių ilgos trukmès diabetu, kenčia nuo periferinès sensorinès neuropatijos (PSN). Šie ligoniai neatkreipia dèmesio ị protarpinio šlubumo simptomus. Ligoniai, sergantys tyliaja išemija, bus priskirti I Fontaine stadijai, o ne II ar III stadijai arba išemija apskritai nebus diagnozuota. Visiems CD sergantiems ligoniams turi būti tikrinama kojų kraujotaka. Svarbus KŽI nustatymas [35, 36]. Mūsų tirtam ligoniui N.P. nustatytas KŽI dex.-0,37, KŽI sin.-0,5. Diagnozuota PAL, abiejų kojų lètinè išemija, stadija IIB-III. İvertintos PSN ir kitų su diabetu susijusių komplikacijų sąsajos. 2 tipo CD sergančių asmenų grupejje tirti 156 asmenys $(61,7 \pm 7,2$ metu, diabeto trukmè - 7,0 \pm 5,7 metu), naudoti klausimynai, atlikti klinikinis, kraujo ir šlapimo tyrimai, analizuota medicininė dokumentacija. PSN paplitimas priklausè nuo retinopatijos sunkumo (50\% dažnis esant vidutinio sunkumo retinopatijai ir 100\% - sunkios ar proliferacinès retinopatijos atveju, $p=0,02$ ). Retinopatija sergančių asmenų vibracijos suvokimo slenkstis buvo didesnis $(25,6 \pm 8,9 \mathrm{~V}$ palyginus su $20,5 \pm 8,9 \mathrm{~V} ; \mathrm{p}=0,007)$. PSN buvo dažnesne ligoniams su nefropatija ir tiems, kuriems buvo aukštesnès vibracijos suvokimo ribos. Ligoniams su PSN be retinopatijos, PAL paplitimas buvo dvigubai didesnis (52\%), palyginus su ligoniais, kuriems buvo PSN ir retinopatija $(19 \%, p=0,05)$. Asmenims tik su PSN, PAL tikimybė buvo tris kartus didesnè ( $52 \%$ ) nei asmenims, kuriems PSN nebuvo $(16 \%, \mathrm{p}=0,001)$. Atliekant multivariacinę analizę nustatyta, kad PSN buvo nepriklausomai susijusi su PAL, amžiumi, vyriška lytimi, DTL cholesterolio kiekiu ir su IGF1 susietu proteinu, bet ne su diabeto trukme ar HbA1C. 2 tipo CD populiacijoje PSN yra susijusi su mikrovaskuline ir makrovaskuline patologija [37]. Siekta ištirti ligonių, sergančių diabetinèmis pėdų opomis, lètines kraujagyslines diabetines komplikacijas ir įvertinti diabetinių pèdų opų ryši su šiomis komplikacijomis. Tirta 180 30-70 metų 2 tipo CD sergančių ligonių, kuriems buvo diabetinès pėdų opos. Diabetinès pedos opos buvo vertintos naudojant Teksaso universiteto diabetinių žaizdų klasifikavimo sistemą. Visiems ligoniams buvo nustatomas HbA1C, MTL-C, kreatinino koncentracija serume ir šlapimo albumino-kreatinino santykis. Apskaičiuotas glomerulų filtracijos greitis (GFG). Visiems atlikta akių dugno apžiūra. Diabetinès nefropatijos ir diabetinès retinopatijos paplitimas tarp tiriamosios grupès asmenų buvo atitinkamai $86,1 \%$ ir $90 \%$. 86,7\% ligonių buvo neuropatinès, $11,1 \%$ - išeminès ir 2,2\% neuroišeminès diabetinès pėdos opos. DPN ir PAL kaip diabetinès pėdos opų rizikos veiksniu paplitimas tiriamojoje grupeje buvo atitinkamai 82 ir 20 procentų. Lètinès diabetinès kraujagyslinès komplikacijos yra dažnos 2 tipo CD sergantiems ligoniams, kuriems yra diabetinès pėdų opos. Nustatytas statistiškai reikšmingas ryšys tarp šių komplikacijų ir DPN bei PAL [38].

Jei PAL ir DPN nediagnozuotos, pédoje gali atsirasti opų. Kadangi šios patologijos yra panašios, gydytojams svarbu mokèti jas atskirti. Yra naujų PAL gydymo būdų, siekiant pagerinti kraujotaką. DPN gydymas paprastai yra paliatyvus, tačiau gali pagerinti ligonio gyvenimo kokybę $[39,40]$. Diabetinių pèdų opos turi būti gydomos tinkamai 
jas ịvertinus. Pateikta nauja keturių lygių diabetinių pėdų opu Kobe klasifikacija: I tipas - vyrauja DPN, II tipas - vyrauja PAL, III - vyrauja infekcija, IV tipas - DPN, PAL, infekcija [41]. Diabetinè pėda apima giliųjų pėdos audinių infekciją, išopejimą ar destrukciją, susijusią su neuropatija ar PAL [42]. PAL, DPN ir imunopatijos derinys sukelia tokių patologijų kaskadą kaip išemija, tendinopatija, atrofija, edema, deformacija, neuropatinè osteoartropatija, opos ir infekcija. Susilpnejjęs ar išnykęs pulsas, pėdos blyškumas ją pakèlus, pèdos paraudimas nuleidus koją, vangus pirštų kapiliarų užpildymas ir nagų sustorèjimas, pirštų plaukų nebuvimas yra pèdos sutrikusios arterinès perfuzijos požymiai. Kai išemija prisideda prie opų ir infekcijos diabetinèje pédoje, jos sunkumą sudètinga nustatyti. Standartinis klinikinis trofinių pokyčių vertinimas yra ribotas užkrèstoje pėdoje su edema ir eritema. Apčiuopiamas pulsas neatmeta galūnių išemijos grèsmès. Šiems ligoniams turi būti atliekami papildomi neinvaziniai kraujagyslių tyrimai. Diabetinès pėdos gydymas dažnai yra sudètinga klinikiné problema. Kai yra infekcijos požymių, būtina atlikti tinkamą drenažą ir skirti antibiotikų terapiją. Kitas žingsnis - atskirti neuropatines opas nuo išeminès opos. Ligoniai dažnai yra besimptomiai dèl neuropatijos ir neveiklumo. Prasidejus opai, reikia nedelsiant skirti gydymą. Jei užkrèstą pėdą reikia amputuoti, svarbu stebėti opą kasdien. Sunaikinus infekciją, turètų pasireikšti greiti gijimo požymiai. Jei žaizdos greitai negyja, būtina atlikti arteriografiją. Ankstyvas pedos sepsio nustatymas ir agresyvus chirurginis drenažas, po kurio atliekama revaskuliarizacija, yra labai svarbūs, norint išsaugoti galūnę [43, 44]. Mūsų tirtam ligoniui K.M. buvo diabetinè pėda, kairès pėdos pūlinys. Atlikta kairès pėdos II-IV padikaulių rezekcija, ATA sin. $>50 \%$ stenozès PTA, skirti antibiotikai. Kairès pėdos amputacijos pavyko išvengti. Yra trys pagrindiniai diabetinès pédos opų valdymo metodai: opos pašalinimas, antibiotikai ir revaskuliarizacija. Gydytojų informuotumas apie diabetu sergančių ligonių pèdų problemas, klinikiniai tyrimai ir paraklinikinis įvertinimas, reguliarus pèdų tyrimas, ligonių mokymas, paprastos higienos praktikos ir tinkamos avalynės nešiojimas kartu su greitu nesunkių traumu gydymu gali sumažinti opų atsiradimą 50 procentų [6]. Atlikta perspektyvi 50 diabetinès pèdos opos atvejų stebėjimo studija. Ji atskleide, kad diabetinès pédos opos nèra retos komplikacijos. Tirti 41 - 50 metų ligoniai, vidutinis amžius - 55 \pm 15 metų, vyrų ir moterų santykis $1,4: 1$. Studija parodè, kad diabetinès pédos opos buvo labiau paplitusios žemos socialinès ir ekonominès grupès ligoniams, tarp rūkalių, tarp blogai kontroliuojamos glikemijos ligonių ir ilgą laiką sergančių diabetu. $92 \%$ ligonių sirgo DPN, $22 \%$ buvo pėdu deformacijos, 70\% - kojų kraujagyslių nepakankamumas. $68 \%$ ligonių pasireiškè ankstyva diabetinè komplikacija, todèl tinkamai gydant, šiems ligoniams galūnę galima išsaugoti [45]. Pateikta standartizuota „Buerger“ fizinių pratimų programa ir ištirtas jos veiksmingumas, mažinant periferinę neurovaskulopatiją 2 tipo CD sergantiems ligoniams, kuriems yra didele rizika susirgti diabetinès pèdos opomis. Šioje studijoje dalyvavo 31 iš 66(47\%) tiriamujų. Buergerio pratimai kartu su sveikatą stiprinančia programa žymiai pagerino KŽI, sveikatą skatinanti elgesi, Mičigano neuropatijos atrankos testo duomenis, sumažino diskomforto simptomus kojose [46].

Skiriamas dèmesys diabeto komplikaciju prevencijai. Diabetinė arteriopatija, apimanti endotelio disfunkciją, uždegimą, hiperkoaguliaciją, kraujotakos pokyčius ir trombocitu anomalijas, prisideda prie ankstyvos makrovaskulinių ivykių raidos. Dabartiniu metu stengiamasi nustatyti intervencijas, kurios gali užkirsti kelią CD komplikacijoms arba jas sustabdyti. Griežta gliukozès ir kraujospūdžio kontrolè pagerina sergančiụjų CD kraujagyslių būklę. Naudinga vartoti priešuždegiminius vaistus ir mažinti mažo tankio lipoproteinų cholesterolio (MTL-C) kiekį. Atsiradęs supratimas apie MTL-C svarbą ir priešuždegiminị statinų poveikị suteikè naujų algoritmų pirminei makrovaskulinės ligos prevencijai. Irodyta, kad antitrombocitiniai vaistai veiksmingi antrinei širdies ir kraujagyslių ligų prevencijai. Būtų idealu, jeigu būtų veikiami visi rizikos veiksniai, o kiekvienas sergantis CD asmuo turètų puikią glikemijos kontrolę, žemą ar normalų AKS ir žemą MTL lygị bei vartotų AKFI kartu su statinu, aspirinu, klopidogreliu. Tokiu būdu galètų būti sustabdyta kylanti makrovaskulinių ligų epidemija. Mikrovaskulinè liga, priešingai, yra hiperglikemijos pasekmè. Sumažinus glikolizinto hemogobino kiekį 1\%, mikrovaskulinès komplikacijos sumažètų 22-35 procentais. AKS kontrole yra gyvybiškai svarbi, o AKFI ir ARB vartojimas norint sulètinti nefropatijos progresavimą turètų smarkiai sumažinti aklumo, dializès ir amputacijų dažni [47]. Prevencinès strategijos sumažina galimą riziką susirgti diabetinèmis pėdų opomis, pèdų infekcija, Charcot pèda ir padeda išvengti amputacijos. Reikètų atsižvelgti i penkis pagrindinius prevencijos punktus: reguliarią pėdų ir avalynès apžiūrą, didelès rizikos ligonių nustatymą, ligonio ir šeimos švietimą, tinkamą avalynę ir nepūlinès patologijos gydymą. Naudojant Semmes -Weinstein testą, kiekvienam ligoniui gali būti priskirta viena iš keturių rizikos kategorijų, kuri padètų valdyti procesą. Pèdų priežiūros programos turi būti teikiamos didelès rizikos ligonių kategorijoms. Veiksmingas ligonių švietimas gali sumažinti pèdų opų ir amputacijų dažnį daugiau kaip 50 procentų [13, 48, 49].

Svarbi ankstyva 2 tipo CD sergančiujų periferinès neuropatijos ir angiopatijos diagnostika ir gydymas, siekiant išvengti diabetinès pèdos opų, infekcijos ir galūnès amputacijos. 


\section{Išvados}

1. Periferinè neuropatija ir angiopatija yra diabetinès pèdos opų rizikos veiksniai.

2. Visiems diabetu sergantiems ligoniams turi būti tikrinama kojų kraujotaka. Svarbus kulkšnies - žasto indekso nustatymas.

3. Yra trys pagrindiniai diabetinès pėdos opų valdymo metodai: opos pašalinimas, antibiotikoterapija ir revaskuliarizacija.

4. Diabetinès pèdos priežiūros principai: gliukozès ir hemoglobino HbA1C kontrole, širdies ir kraujagyslių ligu rizikos veiksnių valdymas, rūkymo nutraukimas, infekcijos kontrolè. Didelès rizikos pacientai turètų dalyvauti pèdų priežiūros programoje.

5. Anksti diagnozavus diabetinę periferinę neuropatiją ir angiopatiją bei paskyrus gydymą, galima išvengti pẻos opų ir amputacijos. Tinkamas standartiniu gydymo strategijų laikymasis ir tarpdisciplininis bendradarbiavimas gali sumažinti amputacijų dažnį.

\section{Literatūra}

1. Cooper ME, Gilbert RE, Jerums G. Diabetic vascular complications. Clin Exp Pharmacol Physiol 1997; 24(9-10): 770-5.

https://doi.org/10.1111/j.1440-1681.1997.tb02130.x

2. Chudzik W, Kaczorowska B, Przybyla M, Chudzik B, Galka M. Diabetic neuropathy. Pol Merkur Lekarski 2007; 22(127): 66-9.

3. Hicks CW, Selvin E. Epidemiology of peripheral neuropathy and lower extremity disease in diabetes. Curr Diab Rep 2019; 27; 19(10): 86. https://doi.org/10.1007/s11892-019-1212-8

4. Karrer S. Diabetic foot syndrome. Hautarzt 2011; 62(7): 493-503. https://doi.org/10.1007/s00105-010-2112-7

5. Lobman R. Neuropathy and diabetic foot ulcers. Internist (Berl) 2015; 56(5): 503-12. https://doi.org/10.1007/s00108-014-3630-7

6. Fard AS, Esmaelzadeh M, Larijani B. Assessment and treatment of diabetic foot ulcer. Int J Clin Pract 2007;61(11): 1931-8. https://doi.org/10.1111/j.1742-1241.2007.01534.x

7. Simms M. Surgical treatment of the neuroischemic foot. J Cardiovasc Surg (Torino) 2009; 50(3): 293-311.

8. Bajaj S, Mahajan A, Grover S, Mahajan V, Goyal P, Gupta VK. Peripheral vascular disease in patients with diabetic foot ulcers - an emerging trend: a prospective study from North India. J Assoc Physicians India 2017; 65(5): 14-17.

9. Boulton AJ. The diabetic foot: a global view. Diabetes Metab Res Rev 2000; 16(1): 2-5. https://doi.org/10.1002/1520-7560(200009/10)16:1+<::AIDDMRR105>3.0.CO;2-N

10. Flyvbjerg A. Diabetic angiopathy, the complement system and the tumor necrosis factor superfamily. Nat Rev Endocrinol 2010; 6(2): 94-101. https://doi.org/10.1038/nrendo.2009.266

11. Borge VM, Morena LH, Dufourny IC, Martinez AF, Pallardo Sánchez LF. Diabetic foot and risk factors. An Med Interna
2007; 24(6): 263-6.

12. Salvotelli L, Stoico V, Perrone F, Cacciatori V, Brangani C, Pichiri I et al. Prevalence of neuropathy in type 2 diabetic patients and its association with other diabetes complications: the Verona diabetic foot screening program. J Diabetes Complications 2015; 29(8): 1066-70.

https://doi.org/10.1016/j.jdiacomp.2015.06.014

13. Boulton AJ. Lowering the risk of neuropathy, foot ulcers and amputacions. Diabet Med 1998; 15(4): 557-9.

https://doi.org/10.1002/(SICI)10969136(1998120)15:4+<S5 7::AID-DIA741>3.3.CO;2-4

14. Agrawal RP, Ola V, Bishnoi P, Gothwal S, Sirohi P, Agrawal R. Prevalence of micro - and macrovascular complications and their risk factors in type 2 diabetus mellitus. J Assoc Physicians India 2014; 62(6): 504-8.

15. Tesfaye S, Malik R, Ward JD. Vascular factors in diabetic neuropathy. Diabetologia 1994; 37(9): 847-54. https://doi.org/10.1007/BF00400938

16. Samuelsson K, Press R. Microangiopathy - a potential contributing factor to idiopathic polyneuropathy: a mini review. Front Neurol 2018; 12; 9:43. https://doi.org/10.3389/fneur.2018.00043

17. Kuiper JP. Symptomatology and diagnosis of the diabetic foot. Phlebologie 1988; 41(1): 3-11.

18. Fang F, Wang J, Wang YF, Peng YD. Microangiopathy I diabetic polyneuropathy revisited. Rur Rev Med Pharmacol Sci 2018; 22(19): 6456-6462.

19. Horovitz SH. Diabetic neuropathy. Clin Orthop Relat Res 1993; 296:78-85.

https://doi.org/10.1097/00003086-199311000-00015

20. Hammes HP. Pathophysiological mechanisms of diabetic angiopathy. J Diabetes Complications 2003: 17(2): 16-9. https://doi.org/10.1016/S1056-8727(02)00275-1

21. Otero-Siliceo E, Ruano-Calderón LA. Diabetic neuropathy: vascular disease? Rev Neurol 2003; 1-15; 37(7): 658-61. https://doi.org/10.33588/rn.3707.2002486

22. Saltykov BB, Zinov'eva OE. Interconnection of the angiopathy and neuropathy development mechanism at patients with type 2 pancreatic diabetes. Arkh Patol 2012; 74(3): 26-9.

23. Popescu RM, Cotutiu C, Graur M, Căruntu ID. Vascular and nerve lesions of the diabetic foot - a morphological study. Rom J Morphol Embryol 2010; 51(3): 483-8.

24. Bosevski M. Diabetic angiopathy. Angiol Sosud Khir 2011; 17(4): 14-23.

25. Jennings PE, Nightingale S, Lawson N, Williamson JR, Barnett $\mathrm{AH}$. Impact of microangiopathy on symptomatic peripheral neuropathy. Diabetes Res 1990; 13(2): 51-4.

26. Vogelberg KH, Mayer P, König M. Decrease of macrovascular hyperemic response of blood flow in diabetics with arterial neuropathy. Klin Wochenschr 1990; 19; 68(12): 588-93. https://doi.org/10.1007/BF01660955

27. Moon JS, Clark V, Beabout JW, Swee RG, Dyck PJ. A controlled study of medial arterial calcification of legs: implications for diabetic polyneuropathy. Arch Neurol 2011; 68(10): 1290-4. https://doi.org/10.1001/archneurol.2011.211

28. Nosenko EM, Sidorenko BA, Koshkin VM, Dadova LV, Gracheva OA, Koshkina IV et al. Clinical manifestations and 
characteristics of vascular led involvement in atherosclerosis of lower extremities in patients with type 2 diabetes. Kardiologia 2003; 43(3): 36-42.

29. Picardo AA, Martinez EE, Martin BG. Comparison of thermal foot maps between diabetic patients with neuropathic, vascular, neurovascular and no complications. Curr Diabetes Rev 2019; 15(6): 503-509.

https://doi.org/10.2174/1573399815666190206160711

30. Turmin MC, Bonnans SS, Chauchard MC, Deglise P, Journot $\mathrm{C}$, Lapeyre $\mathrm{Y}$ et al. DIABSAT telemedicine itinerant screening of chronic complications of diabetes using a satellite. Telemed J E Health 2017; 23(5): 397-403.

https://doi.org/10.1089/tmj.2016.0185

31. Guerrero RM, Vásquez C, Millán SI, Hernández BT, Iloyos RC. Association between neuropathy and peripheral vascular insufficienty in patients with diabetus mellitus type 2 . Rev Invest Clin 2011; 63(6): 621-9.

32. Lin S, Lin C, Wang A, Zhao S, Yan L, Wang P et al. A multicenter survey on the diabetic foot and its neuropathy in China. Zhonghua Yi Xue Za Zhi 2007; 15; 87(18): 1241-4.

33. Koyuncu BU, Karaca M, Sari F, Sari R. Is skin associated with diabetic macro - and microangiopathy? J Nati Med Assoc 2018; 110(6): 574-578. https://doi.org/10.1016/j.jnma.2018.03.003

34. Viswanathan V, Thomas N, Tandon N, Asirvatham A, Rajasekar $\mathrm{S}$, Ramachandran A et al. Profile of diabetic foot complications and its associated complications - a multicentric study from India. J Assoc Physicians India 2005; 53: 933-6.

35 . Head J. Painful diabetic neuropathy - providing the best patient service. Diabetes Metab Res Rev 2003; 19(1): 22-8. https://doi.org/10.1002/dmrr.358

36. Dreyer M. Peripheral artery disease and disorders of microcirculation in patients with diabetes mellitus. Internist (Berl) 2011; 52(5): 533-8. https://doi.org/10.1007/s00108-010-2734-y

37. Kärvestedt L, Märtensson E, Grill V, Elofsson S, Wendt G, Hamsten A et al. Peripheral sensory neuropathy associates with micro - or macroangiopathy: results from a population - based study of type 2 diabetic patients in Sweden. Diabetes Care 2009; 32(2): 317-22. https://doi.org/10.2337/dc08-1250

38. Megallaa MH, Ismail AA, Zeitoun MH, Khalifa MS. Association of diabetic foot ulcers with chronic vascular diabetic complications in patients with type 2 diabetes. Diabetes Metab Syndr 2019; 13(2): 1287-1292. https://doi.org/10.1016/j.dsx.2019.01.048

39. Harley JR. Preventing diabetic foot disease. Nurse Pract 1993; 18(10): 37-8, 41-4. https://doi.org/10.1097/00006205-199310000-00007

40. Bonham PA. Assessment and management of patients with venous, arterial and diabetic/neuropathic lower extremity wounds. AACN Clin Issues 2003; 14(4): 442-56. https://doi.org/10.1097/00044067-200311000-00005

41. Terashi H, Kitano I, Tsuji Y. Total management of diabetic foot ulcerations - Kobe classification as a new classification of diabetic foot wounds. Case Reports. Keio J Med 2011; 60(1): 17-21.

https://doi.org/10.2302/kjm.60.17
42. Lowe S, Kajoumi M. Diabetic, neuropathic, arteriopathic foot and dressing choice. Praxis (Bern 1994) 2012; 14; 101(23): 1489-95. https://doi.org/10.1024/1661-8157/a001110

43. Morrison WB, Ledermann NP. Work-up of the diabetic foot. Radiol Clin North Am 2002; 40(5): 1171-92. https://doi.org/10.1016/S0033-8389(02)00036-2

44. Sumpio BE, Lee T, Blume PA. Vascular evaluation and arterial reconstruction of the diabetic foot. Clin Podiatr Med Surg 2003; 20(4): 689-708. https://doi.org/10.1016/S0891-8422(03)00088-0

45. Quddus MA, Uddin MJ. Evaluation of foot ulcers in diabetic patients. Mymensingh Med J 2013; 22(3): 527-32.

46. Chang CF, Cheng CC, Hwang SL, Chen MY. Effects of buerger exercise combined health - promoting program on peripheral neurovasculopathy among community residents at high risk for diabetic foot ulceration. Worldviews Evid Based Nurs 2015; 12(3): 145-53. https://doi.org/10.1111/wvn.12091

47. Vinik A, Vinik E. Prevention of the complications of diabetes. Am J Manag Care 2003; 9(3): 63-80.

48. Martini J. Diabetic foot: detection and prevention. Rev Med Interne 2008; 29(2): 260-3. https://doi.org/10.1016/S0248-8663(08)73954-7

49. Pinzur MS. Diabetic peripheral neuropathy. Foot Ankle Clin 2011; 16(2): 345-9.

https://doi.org/10.1016/j.fcl.2011.01.002

\section{PERIPHERAL NEUROPATHY AND ANGIOPATHY IN PATIENTS WITH TYPE 2 DIABETES \\ L. Kimševaitė}

Keywords: diabetes, peripheral neuropathy, angiopathy, diabetic foot.

Summary

The article analyses the complications of diabetes - diabetic peripheral neuropathy and diabetic angiopathy. Peripheral neuropathy and angiopathy are the risk factors for diabetic foot ulcers. The blood flow in the legs should be checked in all diabetic patients, the determination of the ankle-brachial index is important. Ulcer removal, antibiotic therapy, and revascularization are key techniques for managing diabetic foot ulcers. Glucose and hemoglobin $\mathrm{HbA1C}$ control, cardiovascular risk management, smoking cessation, and infection control are the principles of diabetic foot care. High-risk patients should participate in a foot care programme. Early diagnosis of peripheral neuropathy and angiopathy and prescribed treatment can prevent foot ulcers and amputation. Clinical cases of diabetic peripheral neuropathy and angiopathy have been presented. The latest scientific literature on peripheral neuropathy and angiopathy in type 2 diabetes has been reviewed.

Correspondence to: liudmila.kimsevaite@gmail.com Gauta 2021-09-02

\section{Straipsnio spausdinimą remia farmacijos kompanija UAB Teva Baltics Molètų pl. 5, LT-08409 Vilnius, tel. +37052360561}

